\title{
Targeting Inducible Nitric Oxide Synthase (iNOS) in The Prevention of Vascular Damage and Cardiac Inflammation
}

Nafees Uddin Chowdhury ${ }^{a}$, Abida Tisha ${ }^{b}$, Juthika Sarker ${ }^{b}$, Pulak Dev Nath ${ }^{b}$, Nowshin Ahmed ${ }^{b}$, Shahanshah Abdullah ${ }^{b}$, Tasdik Farooq ${ }^{b}$, Waich Mahmud ${ }^{b}$, Md. Mohabbulla Mohib ${ }^{b, c}$, Md. Abu Taher Sagor ${ }^{b}$

\begin{abstract}
Vascular damage and subsequent cardiac failure due to immune cytokines is steadily increasing the morbidity of cardiovascular diseases (CVD), making them the leading cause of death globally. Nevertheless, improper diagnosis is an important hurdle in case management. Free radicals are one of major factors in producing vascular abnormalities in CVD. Additionally, some other factors such as high blood pressure, myocardial injuries, vascular damage, ventricular hypertrophy, cardiac fibrosis and myocardial necrosis are also the results of free radical-mediated abnormal cardiac activity/function. Of note, Nitric Oxide Synthase (iNOS) is produced in the body at an elevated rate in the presence of free radicals which has been shown to lead to cardiac issues. Furthermore, iNOS is also increased due to cytoplasmic stress, faulty DNA replication and membrane potential impairment. Moreover, abnormal cardiac rhythm has also been reported to be linked to the presence of iNOS. iNOS can also lead to abnormal cardiac function through inhibition of mitochondrial activity and production of pro-inflammatory cytokines. The molecular mechanism of iNOS that leads to CVD is comprehensively summarized in this review so as to aid in drug discovery strategies for the treatment of CVD.
\end{abstract}

Keywords: iNOS, Immunity, Inflammation, Hypertension, vascular damage

Significance| This study can accelerate in developing antagonists of iNOS to prevent cardiac dysfunctions

${ }^{*}$ Correspondence: Md. Abu Taher Sagor, Department of Pharmaceutical Sciences, North South University, Dhaka-1229, Bangladesh.

Phone: +8801719130130, E mail: sagor2008nsu@gmail.com

Edited by Md Shamsuddin S. Khan, Hawkesbury Institute for the Environment, University of Western Sydney, Hawkesbury Campus, Bourke Street, Richmond, NSW AUSTRALIA, and accepted by the Editorial Board October 7, 2018 (received for review September 2, 2018).
Abbreviations: iNOS - Nitric Oxide Synthase

\section{Introduction}

Hepatic disabilities and renal insufficiency have often been linked with vascular dysfunctions. In addition, excess circulating fat accumulation may potentiate the development of arterial constriction. Of note, systemic hypertension seems to play a central role in myocardium damage and, as a result, several vascular diseases such as angina, myocardial infarction and congestive heart failure have been reported (Abu Taher Sagor; Mohib, Rabby, Paran, Hasan, Ahmed, Hasan, Sagor, Mohiuddin, et al., 2016; Md. Abu Taher Sagor, Nabila Tabassum, Md. Abdullah Potol, \& Md. Ashraful Alam, 2015). Taken together, cardiac insufficiencies and vascular dysfunctions have been the leading cause of death globally. According to the Department of Health and Human Services (DHHS), roughly 596,577 people have died in 2011-14 due to heart diseases in the USA only. With the advancement of medical treatments, the rare of death 3\% was less compared to 1980's but it is still high to minimize the phenomena (Heron \& Anderson, 2016).

Inducible Nitric Oxide Synthase (iNOS), is a critical enzyme involved in cellular growth, migration and fibrosis. It is also implicated in inflammation, which uncontrolled, can lead to cardiac sepsis, dilated cardiomyopathy, myocarditis, ischemia, uncontrolled hypertension and transplant rejection (Alam, Chowdhury, Jain, Sagor, \& Reza, 2015; Mungrue et al., 2002b). Risk factors such as arterial fat deposition, smoking, chronic alcoholism, and genetic predispositions are considered to be inducers of iNOS, thereby correlating them with cardiac disabilities (Crump, Sund-

\footnotetext{
Author Affiliation:

a Department of Prosthodontics, Kumudini Women's Medical College, Dental Unit, Mirzapur, Tangail, Bangladesh.

${ }^{b}$ Department of Pharmaceutical Sciences, School of Life Sciences, North South University, Dhaka, Bangladesh.

${ }^{\mathrm{C}}$ Research Institute for Medicines (iMed.ULisboa), Faculty of Pharmacy, Universidade de Lisboa

Please cite this article:

Chowdhury, Nafees Uddin; Tisha, Abida; Sarker, Juthika; Nath, Pulak Dev; Ahmed, Nowshin; Abdullah, Shahanshah; Farooq, Tasdik; Mahmud, Waich; Mohib, Md. Mohabbulla; Sagor, Md. Abu Taher. (2018).Targeting inducible Nitric Oxide Synthase (iNOS) in the prevention of vascular damage and cardiac inflammation in CVD. Angiotherapy, 1(2), pages 067-077.
} 
quist, Winkleby, \& Sundquist, 2017; Eckel, 1997). Multiple studies have suggested that iNOS-mediated pathways play the central role in cardiac cell dysfunction. In animal models, overexpression of iNOS in the myocardium leads to peroxynitrite over-production which further progresses edema, increases heart volume and can lead to heart block and sudden death (Mungrue et al., 2002b; Md Abu Taher Sagor, Nabila Tabassum, Md Abdullah Potol, \& Md Ashraful Alam, 2015). On the contrary, a contra indicatory experiment showed that much cardiac damages in animal model interacting with iNOS (Heger et al., 2002). Along with the animal models, various clinical investigations have linked iNOS to heart failure (Haywood et al., 1996). Some studies have suggested that iNOS or $\mathrm{NOS}_{2}$ may act as a longer-lasting nitric oxide, thus indicating cytotoxic abilities, which can lead to reduced myocyte contractility and eventual cardiac death (Vejlstrup et al., 1998). On top of this, iNOS is currently being considered as potent inflammatory cytokine that is often associated with a series of phenomenon that ultimately stop the heartbeat (Csont et al., 2005; Mungrue et al., 2002a). In addition to these, several other factors such as transforming growth factor- $\beta$, plasminogen activator factor, platelet-derived growth factor, vascular endothelial growth factor, tumor necrosis factor- $\alpha$, monocyte chemoattractant protein-1 (MCP), mast cell accumulation, C-reactive protein and lipoprotein-associated phospholipase $\mathrm{A}_{2}$ also contribute to myocyte damage and can lead to cardiac mortality (Ballantyne \& Nambi, 2005; Eggers, Oldgren, Nordenskjöld, \& Lindahl, 2004; Fukumura et al., 2001). Furthermore, higher Angiotensin production, over-expression of Xanthine Oxidase (XO), Uric Acid (UA), Creatine kinase, Adiponectin, Creatine Kinase-MB and $\alpha$-Troponin have also been linked to iNOS signaling pathways (Mogensen et al., 2004). As iNOS generally acts as a free radical, many studies have suggested that other free radicals like NOX-4, malondialdehyde, superoxide, peroxide, singlet oxide and peroxynitrite may be correlate with iNOS while interacting with each other, which could be more damageable for the heart (Heymes et al., 2003; Mohib, Rabby, Paran, Hasan, Ahmed, Hasan, Sagor, \& Mohiuddin, 2016; Md Abu Taher Sagor et al., 2015).

iNOS expression was observed in several target areas including hepatocytes, macrophages, neutrophils, the colonic epithelium, chondrocytes, Kupffer cells, the pulmonary epithelium, the vasculature, and in diverse neoplastic diseases (Asano et al., 1994; Charles et al., 1993; MacMicking, Xie, \& Nathan, 1997). A study suggested that preventing iNOS may enhance the activity of $\beta$-adrenergic inotropic responsiveness in an animal model (Funakoshi, Kubota, Kawamura, et al., 2002). Similar studies also showed that blocking iNOS by using ONO-1714 improved ventricular performance and $\boldsymbol{\beta}$-adrenergic inotropic responsiveness to tumor necrosis factor (TNF)- $\alpha$ thus developping dilated cardiomyopathy with myocardial inflammation in TG mice
(Funakoshi, Kubota, Machida, et al., 2002). However, another study suggested that the iNOS/NO/cGMP pathway is more aggressive in senior subjects compared to the younger, thus suggesting that preventing iNOS could be an alternative strategy to protect the cardio-vascular system (Yang, Larson, \& Watson, 2004). Hence, a clear understanding of all the iNOS-related signaling pathways has yet to be established. Therefore, this study will attempt to explain some possible patho-physiology related to iNOS and give numerous treatment approach ideas that could prevent cardio vascular dysfunctions.

\section{iNOS and its regulations}

Nitric oxide (NO) is an important component that works in both intracellular and extracellular pathways. At the same time, it monitors and maintains several signaling pathways for patho-physiological, pharmacological and physiological responses by regulating neuronal activities, cardiovascular responses, cytokine production, anti-microbial and anti-tumor activities (Abu Taher Sagor et al., 2016; Aktan, 2004). In living creatures, nitric oxide also plays an essential role as contrasting roles in case of sustaining differentiation process (Kengatharan, De Kimpe, Robson, Foster, \& Thiemermann, 1998; J. D. MacMicking et al., 1997). The production of NO is very complex and is maintained and regulated by proteins of the Nitric oxide synthase (NOS) family. Nitric Oxide however, was found to have a very short half-life and is therefore produced as needed. For example, organs wherein eNOS is produced use it for vasodilatation. nNOS, on the other hand, produced in neuronal cells, helps in cell communication. In addition, iNOS, is generally expressed in the heart and immune cells where it has been linked to pathogenesis progression. bNOS is mainly expressed in bacterial cells and plays several roles antibiotic resistance, immunity and oxidative stress (Alderton, Cooper, \& Knowles, 2001). On top of these, Osteoarthritic NOS has controversially expressed and created some interesting contents though it is correlated with iNOS and IL-1 (Charles et al., 1993). Another groundbreaking discovery with Guinea-pig iNOS has drawn some interesting correlations in cell and protein cloning for novel discoveries. Guinea-pig iNOS was further correlated with nNOS and bNOS; while others correlated it with iNOS. Hence, correlations have yet to be made clear (Daff, Sagami, \& Shimizu, 1999; Salerno et al., 1997).

On the other hand, nitric oxide is a gas in nature and a very small compound that can freely diffuse into cells wherever it may be needed. The formation and biosynthesis of this product is quite complex and regulated through several factor and co-factors but it has been shown to be biosynthesized from L-arginine. To complete the whole, oxygen is used with NADPH as electron donor, a Heme molecule, FAD, tetrahydrobiopterin (H4B) and FMN. The entire process uses other cofactors and five electrons (Alderton et al., 2001). This process is conducted in two phases i) oxidative exchange of L-arginine to nitric oxide and ii) L-citrul- 


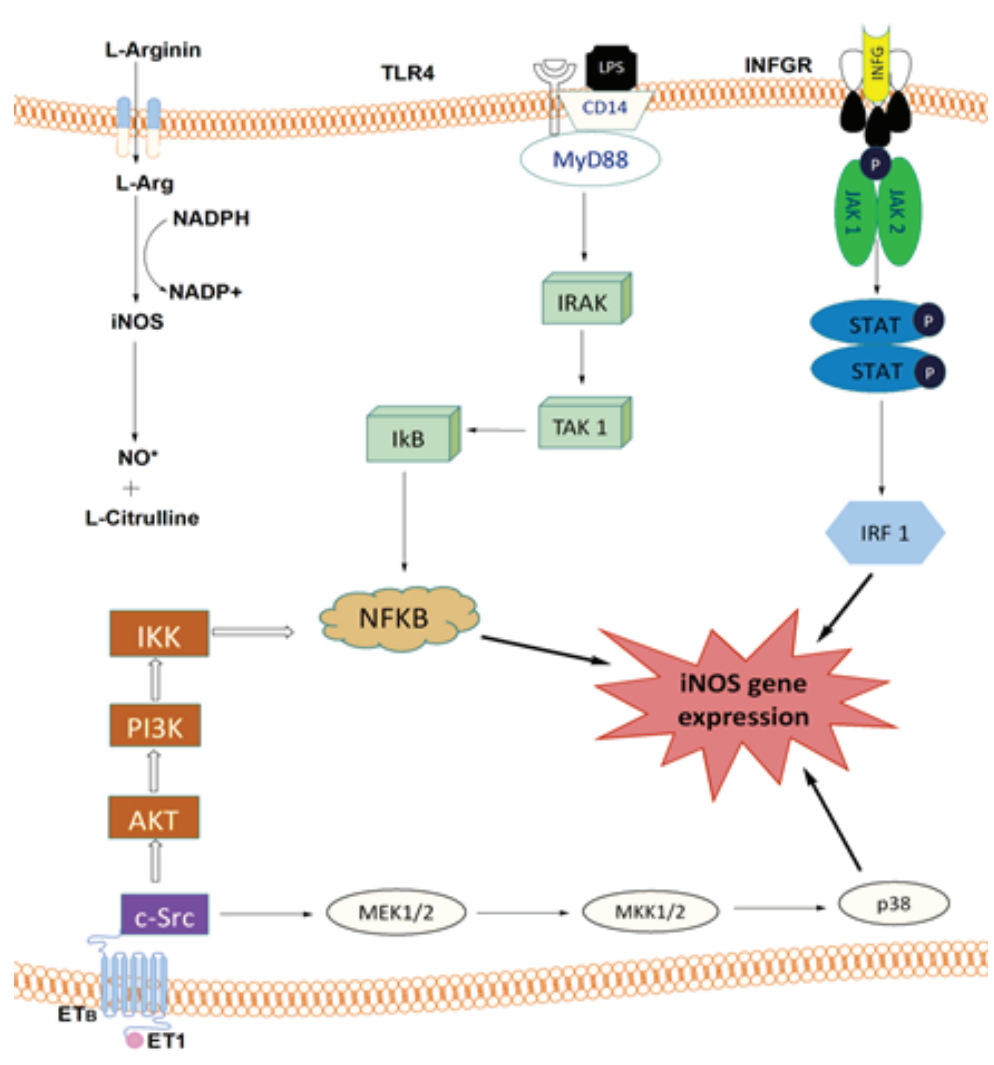

Figure 1 | Multiple signaling pathways are responsible for the biosynthesis of iNOS. L-Arginin plays the prime role to initiates the synthesis, L-Arginine eventually releases NO-free radicals and L-Citrulline into the cell. On the other hand, activation of endothelin receptors causes iNOS gene expression by activating NF- $\kappa$ B and p38. Stimulation of Toll-Like receptor (TLR)-4 and interferon- $\gamma$ receptor (INFGR) also participates in the expression of iNOS gene. line via N-hydroxy-L-arginine (NOHarginine) which is considered the intermediate product that has been shown to interfere with monooxygenase I and monooxygenase II as a mixed-function oxidation (Mayer \& Hemmens, 1997).

Among the all other NOS genes, iNOS is the most studied as it negatively impacts human health. Since the last three decades, the structure, molecular docking and functions have been investigated to explore new avenues related to disease pathology or physiological function. The iNOS gene is situated on chromosome 17. Mouse and Human iNOS are $80 \%$ similar, while that between eNOS and iNOS is $51 \%$ and nNOS and iNOSis 53\% (Taylor \& Geller, 2000; Xu et al., 1994). Despite of its Ca2+ independent functions, the iNOS complex can non-covalently bind Calmodulin and thus representing a necessary subunit of the isoform (Cho et al., 1992). iNOS genes are highly transcribed following several stimulations such as TNF- $\alpha$, interleukin- $1 \beta$, interferon $-\gamma$ and nuclear factor- $\kappa \mathrm{B}$ (Lowenstein \& Padalko, 2004; Müller-Werdan et al., 1997). Besides this, it can also be triggered by bacterial toxins such as the LPS-MyDD-88 pathway (Nathan, 1992). On top of that, the iNOS gene also contains a special region for binding under hypoxic conditions and thereby translated for further interactions with phorbol esters and lipoarabinomannan (Chan, Chan, \& Schluger, 2001; Ferreiro et al., 2001). Other important signaling regulator such as Janus Tyrosine Kinase (JAK) and Signal Transducers and Activators of Transcription (STAT) play significant roles in iNOS gene expression (Xuan, Guo, Han, Zhu, \& Bolli, 2001). iNOS gene regulation and transcription are highly dependent on the stability of iNOS mRNA stability and potent catalytic activity. Moreover, NF- $\kappa B$, Activator Protein 1 (AP1), Activating Transcription Factor 2 (ATF2), cAMP-responsive elements, and other transcription factors may participate in regulating the transcription of the iNOS gene (Janssen-Heininger, Macara, \& Mossman, 1999; Lechner, Lirk, \& Rieder, 2005)\&amp; Mossman, 1999; Lechner, Lirk, \&amp; Rieder, 2005.

\section{Hypertension Biology}

Hypertension is often defined as a slow killing process to humans. It is very common in the older population, but recently it is has been reported in the middle aged population as well (Alam et al., 2015). The exact reason for developing hypertension is yet to be unraveled but has been suggested that multiple factors such as smoking, diet, obesity and low energy expenditure are the main culprits (Mohib, Rabby, Paran, Hasan, Ahmed, Hasan, Sagor, \& Mohiuddin, 2016). Also, co-morbid conditions such as diabetes and pre-genetic dispositions are also correlated with hypertension (Chowdhury et al., 2016; Mohib et al., 2017). In cardiac cells, higher levels of sodium and calcium lead to hypertension. Similarly, abnormal levels of potassium and magnesium also play definitive roles in hypertension (Loh, Giribabu, \& Salleh, 2017; G. Yu, Cheng, Wang, Zhao, \& Liu, 2017). Inside the heart, damage to small vessels and constriction of arteries, unwanted inflammatory cell migration, excess uric acid and Ang-II and diseases like atherosclerosis may eventually lead to hypertension (AT Sagor et al., 2016; Mohib, Hasan, et al., 2016; Md Abu Taher Sagor et al., 


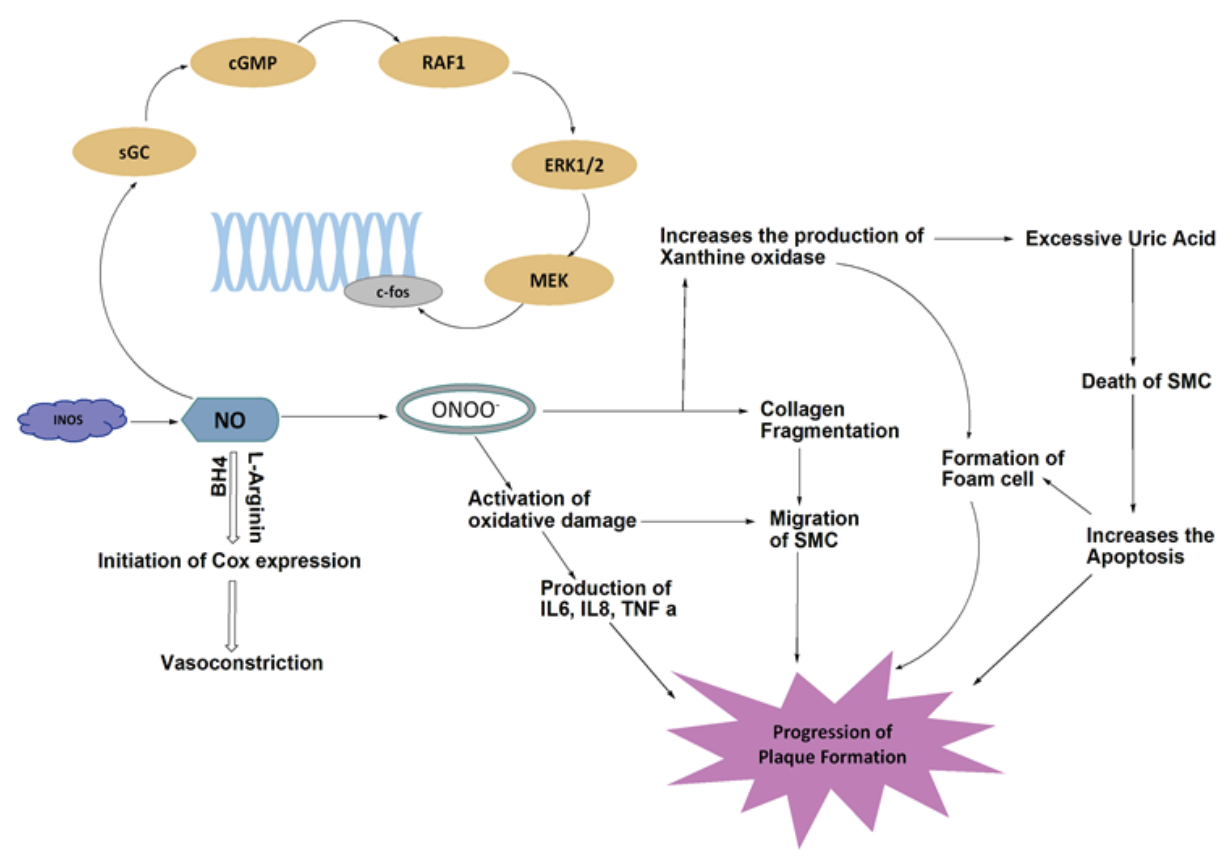

Figure 2 | Nitric Oxide, a free radical processed by iNOS that activates the expression of Cyclooxygenase (Cox) and c-fos transcription factor. It also participates in the activation of collagen and production of inflammatory cytokines which further initiates plaque formation and synthesis of xanthine oxidase (XA) to produce uric acid.

2015). Moreover, less endothelial nitric oxide production can also be the major contributor in the development of arterial pressure (Shabeeh et al., 2017). Left untreated, uncontrolled blood pressure can cause several macrovascular and microvascular diseases like nephropathy, retinopathy, stroke and heart attack by blocking small vessels (Sagor, Mohib, Tabassum, Ahmed, \& Reza, 2016). Several correlations have been drawn so far to connect the possible mechanism for hypertension in response to iNOS. In recent literature, two major possibilities have been tied to increased vasoreactivity and thrombogenesis i) faulty action of peroxynitrite-mediated endothelial NO release, thereby impairing normal vasoreactivity (Seccombe, Pearson, \& Schaff, 1994) and ii) superoxide stimulate platelet adhesion and aggregation binding with peroxynitrite interactions (Salvemini, Nucci, Sneddon, \& Vane, 1989; Seccombe et al., 1994). These two possible theories make change in thrombogenesis and vasoreactivity thus progressing the aggregation of unstable plaque. This leads to iNOS being blamed for thrombus, uncontrolled hypertension and chest pain by increasing vascular hyper-reactivity (Depré, Wijns, Robert, Renkin, \& Havaux, 1997).

\section{Effect of iNOS on vascular damage}

The heart is known as most vascular organ in the body and includes various arteries, vessels, aortas and veins. Blockage or stiffness in the vascular system may reduce blood flow which leads to uncontrolled hypertension leading the way for sudden cardiac failure. Endothelial cells play the most prominent role in the production of nitric oxide (NO) which relaxes arteries for smooth permeability. Besides this, several other factors such as vascular endothelial growth factor (VEGF), platelet-derived growth factor (PDGF), thromboxane and plasminogen activator factor (PAF) maintain and regulate normal blood flow (Figure 2). However, excess production of these growth factors may lead to angiogenesis and even cancers (Zhang, Peng, \& Chen, 2005). Of note, VEGFR-1 and VEGFR-2 are very selective to stimulate endothelial cells. The angiogenic properties of VEGF in human endothelial cells have been associated with nitric oxide production that further leads to angiogenesis (Papapetropoulos, García-Cardeña, Madri, \& Sessa, 1997). In addition, VEGF can influence endothelial cells to produce NO by iNOS signaling (Fukumura et al., 2001). On the other hand, chronic calcification and non-calcified atherosclerotic plaque may cause luminal narrowing in the proximal Right Carotid Artery (RCA) and Left Carotid Artery (LCA) that might further block total cardiac functions. Several animal studies and clinical investigations have been linked many correlations among iNOS, vascular growth and atherosclerosis (M. Xia, Ling, Ma, Kitts, \& Zawistowski, 2003; X. Xia et al., 2006). Furthermore, iNOS is being connected with several cardiac inflammatory markers such as Interleukins, Troponin and Creatinin kinase which are further responsible for the formation of atherosclerotic plaque. Similarly, Macrophages and Foam cells in atherosclerotic plaque may express the inducible isoform of NO synthase (iNOS) which complicates matters as the formation of peroxynitrite from NO can favor vasospasm, stiffness and thrombogenesis (Depre, Havaux, Renkin, Vanoverschelde, \& Wijns, 1999; Luoma et al., 1998). On the contrary, it is of note that NO production by EcNOS impedes against platelet aggregation, leukocyte adhesion and vasoconstriction. However, higher NO production in response to iNOS can positively affect plaque stability through different potential mechanisms thereby triggering numerous vascular dysfunctions (Wever, Lüscher, Cosentino, \& Rabelink, 1998). Other vascular system such as the retina can be affected by iNOS leading to permanent vision loss (D.-H. Lee, Cho, Kim, Choi, \& Joo, 2001). iNOS has also been correlated with acute migraine in human subjects (Palmer et al., 2009).

\section{Role of iNOS on other organs}


Table 1 | Role of iNOS in the cardiovascular dysfunctions on various models

\begin{tabular}{|c|c|c|}
\hline Subjects & Outcomes of the study & References \\
\hline $\begin{array}{l}\text { Model: Mouse Ventricular Myocytes } \\
\text { Induced By: Genetic } \\
\text { Target: Nitric Oxide Signaling }\end{array}$ & Cardiac necrosis and apoptosis were reported. & $\begin{array}{l}\text { (Das, Xi, \& Kukreja, } \\
\text { 2005) }\end{array}$ \\
\hline $\begin{array}{l}\text { Model: Rats } \\
\text { Induced By: Post-ischemic myocardial } \\
\text { surgery } \\
\text { Target: iNOS -VEGF -KDR - eNOS } \\
\text { signaling }\end{array}$ & $\begin{array}{l}\text { Superior post-ischemic ventricular damages, increased } \\
\text { myocardial infarct size and cardiac apoptosis were } \\
\text { found, and Vascular endothelial growth factor noticed } \\
\text { higher. }\end{array}$ & (S. Das et al., 2005) \\
\hline $\begin{array}{l}\text { Model: Vascular Smooth Muscle Cells } \\
\text { Induced By:IL-1 } \alpha \text { and TNF- } \alpha \\
\text { Target: Natriuretic peptides in vascular } \\
\text { remodeling }\end{array}$ & Vascular remodeling was noticed due to iNOS signaling. & (Marumo et al., 1995) \\
\hline $\begin{array}{l}\text { Model: Male SD rats } \\
\text { Induced By: Worm Ischemic } \\
\text { Precondition } \\
\text { Target: iNOS and eNOS }\end{array}$ & $\begin{array}{l}\text { Endothelial dysfunction and ischemia/reperfusion } \\
\text { injury were observed. }\end{array}$ & $\begin{array}{l}\text { (Wang, Fang, } \\
\text { Stepheson, Khiabani, \& } \\
\text { Zamboni, 2004) }\end{array}$ \\
\hline $\begin{array}{l}\text { Model: Rats } \\
\text { Induced By: Endotoxemia } \\
\text { Target: } \\
\text { MEK1/ERK1/2/iNOS/sGC/PKG } \\
\text { pathway }\end{array}$ & Hypotension and vascular hyporeactivity were noticed. & (Korkmaz et al., 2011) \\
\hline $\begin{array}{l}\text { Model: Wistar rats } \\
\text { Induced By: Hyperbaric oxygen } \\
\text { mitigates ischemia-reperfusion } \\
\text { Target: NOS signaling }\end{array}$ & $\begin{array}{l}\text { Ischemia-reperfusion injuries along with higher NOS } \\
\text { were determined. }\end{array}$ & (Baynosa et al., 2013) \\
\hline $\begin{array}{l}\text { Model: Mice } \\
\text { Induced By: High fat diet } \\
\text { Target: Atherosclerotic Plaque }\end{array}$ & $\begin{array}{l}\text { Pro-inflammatory cytokines such as tumor necrosis } \\
\text { factor- } \alpha \text {, arginase- } 2 \text {, Interleukin (IL)- } 1 ß, \text { IL- } 6 \text { and } \\
\text { Interferon- } \gamma \text { noticed to be increased. }\end{array}$ & $\begin{array}{l}\text { (Simsekyilmaz et al., } \\
\text { 2013) }\end{array}$ \\
\hline $\begin{array}{l}\text { Model: RAW } 264.7 \text { macrophages } \\
\text { Induced By: Already Induced } \\
\text { Target: NF- } \kappa \text { B and AP-1 }\end{array}$ & $\begin{array}{l}\text { NF- } \kappa \mathrm{B}, \mathrm{AP}-1 \text { activation and related inflammatory } \\
\text { cytokines found to be increased. }\end{array}$ & (Ryu et al., 2013) \\
\hline $\begin{array}{l}\text { Model: OLP oral tissues samples } \\
\text { Induced By: Induced } \\
\text { Target: VEGF and iNOS }\end{array}$ & $\begin{array}{l}\text {-Expression of VEGF was observed higher in all } \\
\text { epithelial layers, } \\
\text {-Angiogenesis and inflammatory cell infiltrates noticed, } \\
\text { and } \\
\text {-Number of CD68+ cells was significantly increased. }\end{array}$ & $\begin{array}{l}\text { (Metwaly, Ebrahem, \& } \\
\text { Saku, 2014) }\end{array}$ \\
\hline $\begin{array}{l}\text { Model: Vascular Smooth Muscle Cells } \\
\text { Induced By: Genetic } \\
\text { Target: Inflammatory cytokines and } \\
\text { HO-1 pathways }\end{array}$ & $\begin{array}{l}\text {-An increased number of harmful cytokine was } \\
\text { reported, and } \\
\text {-Decreased HO-1 was noticed. }\end{array}$ & $\begin{array}{l}\text { (X.-m. Liu, Peyton, } \\
\text { Wang, \& Durante, } \\
\text { 2012) }\end{array}$ \\
\hline $\begin{array}{l}\text { Model: Spontaneously Hypertensive } \\
\text { Rats } \\
\text { Induced By: Genetic } \\
\text { Target: Arterial natriuretic peptide and } \\
\text { arterial pressure }\end{array}$ & $\begin{array}{l}\text {-Heart, valve and aortic eNOS activity decreased, and } \\
\text {-Abnormal BP was evaluated. }\end{array}$ & (Costa et al., 2010) \\
\hline $\begin{array}{l}\text { Model: Human } \\
\text { Induced By: Acute Global I/R during } \\
\text { Cardiac bypass Surgery } \\
\text { Target: RNase1 }\end{array}$ & $\begin{array}{l}\text {-Cardiac markers were found to be increased, and } \\
\text {-Inflammatory cytokines production (TNF- } \alpha \text { ) noticed } \\
\text { higher. }\end{array}$ & $\begin{array}{l}\text { (Cabrera-Fuentes et al., } \\
\text { 2014) }\end{array}$ \\
\hline
\end{tabular}

The damaging effects of iNOS are not only observed in the vascular systems but it is also found in the intestine (Wong et al., 1996), kidney (Gupta et al., 2007), liver (Dias et al., 2005), pancreas (Shimabukuro, Ohneda, Lee, \& Unger, 1997), brain (Wong et al., 1996), adipose tissues (Kapur, Marcotte, \& Marette, 1999), lung (Sarady et al., 2004) and smooth muscles (Kibbe et al., 2000). Several mechanisms and destructive pathways have been explained so far depending on the iNOS nature. In the lung, iNOS has been linked with inceased production of PGE2 and NO that could further play a major role in the lung's inflammatory or fibrogenic response (J. K. Lee et al., 2012). In the smooth muscles, iNOS upregulates p21 and blocks vascular smooth muscle cell proliferation via $\mathrm{p} 42 / 44$ MAPK activation independently of p53
(Kibbe et al., 2000). iNOS expression in the adipose tissue has been shown to be elevated in adipocytes as they act as artificial production houses of iNOS. The mRNA of iNOS has detected in both white and brown adipocytes and has been further linked with TNF- $\alpha$ and INF- $\gamma$ (Kapur et al., 1999). iNOS expression in the kidney has been investigated, especially in diabetic and fibrosis subjects. Animal model showed higher iNOS expression in diabetic kidneys and that its expression corelates with $\alpha$-SMA, collagen I, fibronectin, TGF $\beta-1, \mathrm{NF}-\kappa \mathrm{B}$, apoptosis and DNA damage (S. Khan \& Jena, 2014). Liver fibrosis has been a bigger target due to having a very complex patho-physiology involvement. iNOS plays a vital role in the production and activation of kuffer cells, which are responsible for extracellular matrix, 
Table 2 | The role of plant extracts against Cardiac and vascular iNOS on various animal model

\begin{tabular}{|c|c|c|}
\hline Subjects & Outcomes of the study & References \\
\hline $\begin{array}{l}\text { Model: Male ICR mice, RAW } \\
264.7 \text { murine macrophages } \\
\text { Wt/Age of model: } 25-30 \mathrm{~g} \\
\text { Plant extract: Angelica decursiva } \\
\text { Dose: } 50,100,200 \mu \mathrm{g} / \mathrm{ml}\end{array}$ & $\begin{array}{l}\text { - Pretreatment with umbelliferone 6-carboxylic acid isolated from : } \\
\text { Angelica decursiva down-regulated the expression of nitric oxide } \\
\text { synthase and inhibited the production of nitric oxide }\end{array}$ & $\begin{array}{l}\text { (Islam et al., } \\
\text { 2012) }\end{array}$ \\
\hline $\begin{array}{l}\text { Model: } 3 \mathrm{~T} 3-\mathrm{L} 1 \text { pre-adipocyte } \\
\text { Plant extract: Punica granatum L. } \\
\text { Dose:0-15.6 } \mu \mathrm{g} / \mathrm{ml}\end{array}$ & $\begin{array}{l}\text {-Pomegranate mesocarp extract from Punica granatum } L \text { down- } \\
\text { regulated the over expression of iNOS. }\end{array}$ & $\begin{array}{l}\text { (Ramlagan et al., } \\
\text { 2017) }\end{array}$ \\
\hline $\begin{array}{l}\text { Model: RINm5F rat pancreatic } \beta \text { - } \\
\text { cell line } \\
\text { Plant extract: Rheum palmatum } \\
\text { Dose: } 15,30 \mu \mathrm{g}\end{array}$ & $\begin{array}{l}\text {-Emodin from Rheum palmatum attenuated iNOS mRNA and } \\
\text { protein levels. }\end{array}$ & (Bae et al., 2015) \\
\hline $\begin{array}{l}\text { Model:EAhy } 926 \text { endothelial cells } \\
\text { Plant extract: Arthrospira platensis } \\
\text { Dose: } 0.05, .10 \mathrm{mg} / \mathrm{ml}\end{array}$ & $\begin{array}{l}\text {-Both polyphenol from } A \text {. platensis and from UV-stressed } A \\
\text { platensis down-regulated the expression of iNOS in a dose } \\
\text { dependent manner. }\end{array}$ & $\begin{array}{l}\text { (Ferrari et al., } \\
\text { 2015) }\end{array}$ \\
\hline $\begin{array}{l}\text { Model: Murine macrophage cell } \\
\text { line RAW } 264.7 \\
\text { Plant extract: Litsea japonica } \\
\text { Dose: } 2.5,5,10 \mu \mathrm{M}\end{array}$ & $\begin{array}{l}\text {-Litsenolide extracted from Litsea japonica down-regulated iNOS } \\
\text { expression and suppressed nitric oxide release on the macrophage } \\
\text { cell line. }\end{array}$ & $\begin{array}{l}\text { (Ham et al., } \\
\text { 2015) }\end{array}$ \\
\hline $\begin{array}{l}\text { Model: RAW } 264.7 \text { Murine } \\
\text { macrophages } \\
\text { Plant extract: Saccharina japonica } \\
\text { Dose: Pheophorbide A } 0.125-1.0 \\
\text { lM, pheophytin A 5-30 lM }\end{array}$ & $\begin{array}{l}\text {-Pre-treatment with pheophorbide and pheophytina extracted from } \\
\text { Saccharina japonica down-regulated the expression of iNOS protein } \\
\text { in a dose dependent manner. }\end{array}$ & $\begin{array}{l}\text { (Islam et al., } \\
\text { 2013) }\end{array}$ \\
\hline $\begin{array}{l}\text { Model: RAW } 264.7 \text { murine } \\
\text { macrophages } \\
\text { Plant extract: Eisenia bicyclis } \\
\text { Dose: } 5,10 \mu \mathrm{M}\end{array}$ & $\begin{array}{l}\text {-Fucosterol from Eisenia bicyclis suppressed iNOS in } \\
\text { lipopolysaccharide induced macrophage cell line and reduced nitric } \\
\text { oxide production. }\end{array}$ & $\begin{array}{l}\text { (Jung, Jin, Ahn, } \\
\text { Lee, \& Choi, } \\
\text { 2013) }\end{array}$ \\
\hline $\begin{array}{l}\text { Model:PC12 cell line } \\
\text { Plant extract: Rhodiolarosea } L . \\
\text { Dose: } 10,50,100 \mu \mathrm{M}\end{array}$ & $\begin{array}{l}\text {-Salidroside extracted from Rhodiolarosea L. counteracted the over- } \\
\text { expression of iNOS protein and reduced the production of nitric } \\
\text { oxide level. }\end{array}$ & (X. Li et al., 2011) \\
\hline $\begin{array}{l}\text { Model: BV-2 microglial cells } \\
\text { Plant extract: Acorus gramineus } \\
\text { Dose: } \beta \text {-asarone: } 10,50,100 \mu \mathrm{M}\end{array}$ & $\begin{array}{l}\text { - } \beta \text {-asarone from Acorus gramineus attenuated iNOS expression in } \\
\text { LPS activated BV-2 microglia cells to exhibit anti-inflammatory } \\
\text { effects. }\end{array}$ & (Lim et al.) \\
\hline $\begin{array}{l}\text { Model- hCB1/hCB2-CHO cells } \\
\text { Plant extract: Cannabis sativa } \\
\text { Dose: Tetrahydrocannabivarin: } 1 \\
\mu \mathrm{M}\end{array}$ & $\begin{array}{l}\text {-Tetrahydrocannabivarin of Cannabis sativa attenuated the iNOS } \\
\text { expression in the lipopolysaccharide induced peritoneal } \\
\text { macrophage. }\end{array}$ & $\begin{array}{l}\text { (Romano et al., } \\
\text { 2016) }\end{array}$ \\
\hline
\end{tabular}

collagen, MMPs and a-SMA production(Anavi et al., 2015; Rodrigues et al., 2017). The $\mathrm{NOS}_{2}$ gene encodes iNOS synthesis and often contributes to antimicrobial and antipathogenic activities. Excess production of iNOS may accelerate in inflammatory bowel disease (IBD) and $\mathrm{NOS}_{2}$ may be implicated in a specific subset of IBD patients with severe and/or extensive colitis (Dhillon et al., 2014). In the brain, iNOS has been correlated with MPO, neutrophil accumulation, ROS generation and NF- $\kappa \mathrm{B}$ signalling due to excess peroxynitrite production (Abdelsalam \& Safar, 2015). In the pancreas, iNOS often induces free radical,inflammatory cytokines and killer cells which ultimately destroys pancreatic $\beta$-cells, resulting in type- 1 diabetes mellitus. Study have shown a possible correlation between the iNOS-2087A>G polymorphism and chronic pancreatitis, which further links it with human diabetes (Pădureanu et al., 2017). Furthermore, iNOS has also been implicated with several types of cancers (Vannini, Kashfi, \& Nath, 2015). Several relationships have been drawn between iNOS and cancer biology. Of those, most of them were identified with inflammatory pathways (Ying \& Hofseth, 2007).

Selective iNOS inhibitors have proven to be effective cancer markers and may help in the progression stages of various abnormal cell replication (Janakiram \& Rao, 2012).

\section{Effect of iNOS on cardiac inflammation}

Cardiac inflammation is one of the major reasons for myocardial injuries and atherosclerosis, which often correlate with cardiac failure (Md Abu Taher Sagor et al., 2015). Several explanations have been put forward as to the exact the reason for cardiac injuries in western diets compared to others. A study reported that western diets can produce more advanced glycation end products (AGE), which interact with receptors for advanced glycation end products (RAGE), which in turn induce cardiac inflammation (Tikellis et al., 2008). Recent reports suggested that cardiac inflammation eventually alters the extracellular matrix in heart failure patients and that phages concurrently contribute to the Heart Failure with Normal Ejection Fraction (HFNEF) rate, ultimately increasing mortality (Westermann et al., 2010). Monocyte Chemoattractant Protein-1 (mcp-1) and its receptor CCR2, on the other hand, were found to be significantly responsible for vascular remodeling and inflammation in hypertension-suffering subjects (Ishibashi et al., 2004). The mRNA of pro-inflammatory cytokines and iNOS have often been evaluated simultaneously 
Table 3 | The role of plant extracts against Cardiac and vascular iNOS on various animal model

\begin{tabular}{|c|c|c|}
\hline Subjects & Outcomes of the study & References \\
\hline $\begin{array}{l}\text { Model: Male ICR mice } \\
\text { Wt of model:28-30g } \\
\text { API used: Lactobacillus sakei K040706 } \\
\text { Dose:108 CFU/day orally for } 12 \text { days }\end{array}$ & $\begin{array}{l}\text {-K040706 attenuated iNOS protein expression in the } \\
\text { colon resulting in anti-inflammatory effects. }\end{array}$ & (Seo et al., 2017) \\
\hline $\begin{array}{l}\text { Model: Male Sprague Dawley rats } \\
\text { Wt of model: } 220-240 \mathrm{~g} \\
\text { API used: } 100 \mathrm{mg} \text { Lansoprazole/kg orally } \\
\text { for } 24 \text { hours }\end{array}$ & $\begin{array}{l}\text {-Lansoprazole reduced iNOS expression in the intestine } \\
\text { of Indomethacin induced rats }\end{array}$ & (Yoda et al., 2010) \\
\hline $\begin{array}{l}\text { Model: T98G human Glioblastoma cell } \\
\text { line } \\
\text { API used: Thalidomide } \\
\text { Dose: } 20 \mu \mathrm{M}\end{array}$ & $\begin{array}{l}\text {-Thalidomide significantly reduced the overexpression } \\
\text { of iNOS in T908G morphine dependent cell line. }\end{array}$ & $\begin{array}{l}\text { (M. I. Khan et al., } \\
\text { 2017) }\end{array}$ \\
\hline $\begin{array}{l}\text { Model: Adult male Wistar rats } \\
\text { Wt of model: } 150-200 \mathrm{~g} \\
\text { API used: } 9 \mathrm{mg} \text { Oral Nimesulide/kg BW } \\
\text { for } 7 \text { days }\end{array}$ & -Nimesulide reduced iNOS expression in the lung & $\begin{array}{l}\text { (Khanduja, Sohi, } \\
\text { Pathak, \& Kaushik, } \\
\text { 2006) }\end{array}$ \\
\hline $\begin{array}{l}\text { Model: Male C57BL/ } 6 \text { mice } \\
\text { Age of model: } 6-8 \text { weeks old } \\
\text { API used: } 5,20 \text { and } 50 \mathrm{mg} \text { oralLuteolin } / \mathrm{kg} \\
\text { for } 18 \text { days }\end{array}$ & $\begin{array}{l}\text {-Lutelin protected mice from colitis through inhibition } \\
\text { of iNOS }\end{array}$ & $\begin{array}{l}\text { (Y. Li, Shen, \& Luo, } \\
\text { 2016) }\end{array}$ \\
\hline $\begin{array}{l}\text { Model: Female ICR mice } \\
\text { Wt of model: } 25 \mathrm{~g} \\
\text { API used: } 10 \text { and } 100 \mathrm{mg} \text { oral Zerumbone } \\
/ \mathrm{kg} / \mathrm{BW} \text { for } 8 \text { days }\end{array}$ & -Dietary Zerumbone repressed iNOS expression. & (Chen et al., 2011) \\
\hline $\begin{array}{l}\text { Model: MS- } 1 \text { cell line } \\
\text { API used: Glucagon like peptide-1 } \\
\text { Dose: } 100 \mathrm{nmol} / \mathrm{L}\end{array}$ & $\begin{array}{l}\text {-GLP-1 suppressed the expression of iNOS to inhibit } \\
\text { the production of NO in microvascular endothelial } \\
\text { cells. }\end{array}$ & $\begin{array}{l}\text { (F.-q. Liu et al., } \\
\text { 2011) }\end{array}$ \\
\hline $\begin{array}{l}\text { Model: Male adult Sprague-Dawley rat } \\
\text { Wt of model:150-200g } \\
\text { API used: Dolastatin 15, Celecoxib } \\
\text { Dose : Oral Dolastatin 15: } 5 \mu \mathrm{g} / \text { day to each } \\
\text { rat; Celecoxib: } 6 \mathrm{mg} / \mathrm{kg} \text { BW for6 weeks }\end{array}$ & $\begin{array}{l}\text {-Dolastatin and Celecoxib inhibited iNOS by } \\
\text { interacting with it directly. }\end{array}$ & $\begin{array}{l}\text { (Piplani, Vaish, \& } \\
\text { Sanyal, 2012) }\end{array}$ \\
\hline $\begin{array}{l}\text { Model: Adult male ICR mice } \\
\text { Wt of model: } 25-30 \mathrm{~g} \\
\text { API used: } 50 \mathrm{mg} \text { oral Tetrahydrocurcumin } \\
\text { and Deferiprone } \mathrm{kg} / \text { day for } 8 \text { weeks }\end{array}$ & $\begin{array}{l}\text {-Tetrahydrocurcumin and Deferiprone inhibited iNOS } \\
\text { expression to alleviate the deleterious cardiovascular } \\
\text { effect of iron overload. }\end{array}$ & $\begin{array}{l}\text { (Sangartit et al., } \\
\text { 2016) }\end{array}$ \\
\hline $\begin{array}{l}\text { Model: } 11 \text { healthy subjects and } 14 \\
\text { hypertensive patients } \\
\text { API used: } 4 \mathrm{mg} \text { oral Lacidipine/day for } 6 \\
\text { months }\end{array}$ & $\begin{array}{l}\text {-Lacidipine reduced iNOS expression in the } \\
\text { macrophage along with alleviation of blood pressure. }\end{array}$ & $\begin{array}{l}\text { (Escames et al., } \\
\text { 2004) }\end{array}$ \\
\hline
\end{tabular}

which makes them interrelated with each other. A population-based study reported that patients with dilated cardiomyopathy showed the presence of iNOS and TNF- $\alpha$ mRNA in their cardiomyocytes (Satoh et al., 1997).

\section{Treatment strategies against iNOS}

As cardio-vascular diseases become an ever increasing concern, the pressure on healthcare professionals to discover novel molecules to treat these issues is elevating. Recent research is trying to focus on plant-based therapies as they are considered quite safe and rarely show any adverse drug reaction (ADR). For instance, Terminalia arjuna bark can reduce multiple cardiac symptoms, complexities and often improve vascular activities (Dwivedi, 2007). On the contrary, several studies suggest that complementary therapies do not have any specific dose or dosage forms, and similarly, some researchers believe that using the whole plant, rather than a purified active compound, is unnecessary (Rasoanaivo, Wright, Willcox, \& Gilbert, 2011). As iNOS is an enzyme, natural therapies must ensure to mitigate any possible secondary protein interactions. Several plant-based therapies have been investigated in the laboratory and found to have suppressive activities against iNOS expression. Indeed, umbelliferone 6-carboxylic acid isolated from Angelica decursiva showed inhibitory activity against iNOS and nitric oxide production in lipopolysaccharide (LPS)-stimulated raw 264.7 macrophages (Islam et al., 2012).

In the laboratory, macrophage or related cell culture has been extremely popular for mimicking and establishing iNOS expression and or inhibition. A study conducted with pomegranate (Punica granatum L.) mesocarp extract found suppressed activity of iNOS expression in the treated adipocytes. Along with the iNOS inhibition, the study also suggested IL- 6 and NF- $\kappa$ B inhibition (Ramlagan et al., 2017). On the other hand, several studies reported that aggregation of inflammatory and pro-inflammatory cytokines interferes with normal cardiac function and disturbs 
vascular activity. An investigation into this phenomena noted suppressed iNOS activity and COX-2 mRNA production when LPS induced RAW264.7 were treated with Litsea japonica fruit-isolated litsenolide B2. Protein investigation also found NF- $\kappa B$ and MAPK pathways inhibition (Ham et al., 2015). Terminalia arjuna is very familiar all over the world and was shown to be very beneficial in several cardiac diseases including coronary arterial dysfunctions (Kapoor, Vijayvergiya, \& Dhawan, 2014). Terminalia arjuna bark contains a new triterpene glycoside which is known as Terminoside which was found to be very protective against murine macrophages by blocking NO and iNOS pathways (Ali et al., 2003). Similarly, pathology of atherosclerosis and neointima formation especially after angioplasty associated with aggregation and proliferation of inflammatory cytokines stimulated by macrophages and vascular smooth muscle cells in the neointima. Terminalia chebula is a very well-known traditional herb containing several phyto-nutrients including that was shown to suppress 1,1-diphenyl-2-picryl hydrazyl (DPPH) scavenging activity and lipid peroxidation breakdown. This plant was also found to be very effective when applied to RAW 264.7 cells and showed inhibitory activity towards iNOS and NO production and platelet-derived growth factor (PDGF-BB) induced VSMC migration (H.-H. Lee, Paudel, \& Kim, 2015). However, cardiac functions largely depend on many electrolytes such as sodium, potassium, magnesium and most importantly calcium. Abnormalities in the ions may negatively affect cardiac function. On the other hand, sarcoplasmic reticulum serves the most prominent role in storing calcium ions and disturbances in sarcoplasmic reticulum may release higher calcium thus increasing cardiac activity and fatiguing the heart within a shorter period. It was previously reported that IL- 6 decreases contractility and increases inducible NOS in the heart of mice. Following that investigation; the same authors conducted another study on L-type $\mathrm{Ca}+$ channel and noticed a negative inotropy role of iNOS on chronic IL-6 exposure in the adult ventricular myocytes. The investigation finally concluded that activation of iNOS mediates IL-6-induced inhibition of SR function. Hence, preventing iNOS can be an excellent way to protect cardiovascular system (X. W. Yu, Chen, Kennedy, \& Liu, 2005).

Endothelial cells directly from animals or Raw endothelial cells are both popular cells that respond to iNOS production. As iNOS-mediated endothelial dysfunction has been highly correlated with the cardiovascular system. With this in mind, preventing or blocking iNOS or NO would be a good approach to protect from heart diseases. Several studies have explained that natural polyphenols-based treatment strategies can block iNOS expression, thereby preventing excess NO production. A study found that Arthrospira platensis is a very potential source of natural polyphenol when applied on endothelial cells, as its polyphenolic property significantly prevent the expression of endothelial Nitric Oxide Synthase, MMP-9, iNOS and Vascular Cell Adhesion Molecule 1 on TNFa-induced endothelial activation (Ferrari et al., 2015).

The heart is the most sophisticated organ in the entire body and any halting of cardiac activity due to however small the problem can have dramatic impacts on the body. It is thus primordial to take good care of the cardiovascular system to keep the other organs running optimally. iNOS, on the other hand, is an enzyme which has a very short biological half-life, meaning that targeting this molecule must be very specific as unwanted protein interaction may occur. As iNOS also interferes in other biochemical pathways, which further trigger other harmful downstream signaling pathways, proper blocking of iNOS might be very beneficial to prevent other diseases. In addition, iNOS also triggers free radical-mediated oxidative stress which damages cardiomyocytes. Researchers are working very hard to discover and design new molecules to inhibit the iNOS pathway. A study suggested that Glucagon-like peptide 1 protects microvascular endothelial cells by interfering with intracellular signaling pathway that activate apoptosis. The study further explained that inactivating the PARP-1/iNOS/NO pathway by treating with Glucagon-like peptide 1 may restore islet microvascular endothelial cells (IMECs) (F.-q. Liu et al., 2011). In these studies, overexpression of iNOS in animal cardiomyocytes triggers peroxynitrite generation, heart block, and sudden death (Mungrue et al., 2002a), further solidifying that need for preventing iNOS to counter cardiac dysfunctions. Expression of COX-2 mRNA is currently being interrelated with the production of iNOS in macrophages and epithelial cells as these mRNAs serve almost the same function. A study found that preventing COX-2 and iNOS by a-tocopherol can inhibit PGE2 production, resulting in protected vascular function (Jiang, Elson-Schwab, Courtemanche, \& Ames, 2000).

Hypertension on the other hand, has been highly correlated with activated iNOS in the systemic circulation, so preventing or blocking iNOS can play an important role in countering arterial pressure. A clinical trial with 25 subjects, 14 of which were hypertensive subjects given $4 \mathrm{mg}$ /day of a lacidipine treatment for six months found that this treatment greatly helped hypertensive subjects. The treatment controlled systemic blood pressure, decreased free radical production, reduced the oxidative damage to the endothelium and decrease iNOS in macrophages without interfering with NO level (Escames, Khaldy, León, González, \& Acuña-Castroviejo, 2004). Nitric Oxide is essential for endothelial cells to relax the arteries, hence, absence of iNOS functions less oxidative stress and related-damages (Sun et al., 2005).

\section{Conclusion}

Evidences suggest that heart dysfunctions are the prime reason for human mortality and morbidity. Studies also showed significant data on hypertension which has been the silent killer of 
mankind. Importantly, iNOS-induced cardiac dysfunctions are mainly through free radical-mediated myocardium injuries, pro-inflammatory and inflammatory-mediated destructions, vascular stiffness and arterial injuries. iNOS often leads to atherosclerosis as well, which further blocks the heart and eventually leads to heart failure. Several researchers now focus on targeting iNOS as a preventative measure against cardio-vascular diseases. Blocking iNOS and its mRNA proves to be highly beneficial in both animal and human models to decrease vascular damaging events. Targeting iNOS may be helpful in the near future to establish novel therapeutic approaches.

\section{Author contributions}

N.U.C. conceived the primary idea and searched all study materials. A.T. prepared the pathways. J.S., P.D.N., N.A., S.A., T.F. and W.M. helped NUC to write the initial chapters and tables. M.M.M. proposed the pathways. N.U.C., M.M.M. and M.A.T.S. finalized the manuscript and trained all group members.

\section{Acknowledgement}

The authors are grateful to Dr. Sarif Mohiuddin, PhD student in Aichi Medical University, Japan to guide us on this manuscript.

\section{Competing financial interests}

Authors have declared that no competing interest exists.

\section{References}

Abdelsalam, R. M., \& Safar, M. M. (2015). Neuroprotective effects of vildagliptin in rat rotenone Parkinson's disease model: role of RAGE-NFkB and Nrf2-antioxidant signaling pathways. Journal of neurochemistry, 133(5), 700-707.

Abu Taher Sagor, M. Angiotensin-II, a potent peptide, participates in the development of hepatic dysfunctions. Immunology, Endocrine \& Metabolic Agents in Medicinal Chemistry, 16, 1-17.

Abu Taher Sagor, M., Mahmud Reza, H., Tabassum, N., Sikder, B., Ulla, A., Subhan, N., . Ashraful Alam, M. (2016). Supplementation of rosemary leaves (Rosmarinus officinalis) powder attenuates oxidative stress, inflammation and fibrosis in carbon tetrachloride $(\mathrm{CCl} 4)$ treated rats. Current Nutrition \& Food Science, 12(4), 288-295.

Aktan, F. (2004). iNOS-mediated nitric oxide production and its regulation. Life sciences, 75(6), 639-653

Alam, M. A., Chowdhury, M. R. H., Jain, P., Sagor, M. A. T., \& Reza, H. M. (2015). DPP-4 inhibitor sitagliptin prevents inflammation and oxidative stress of heart and kidney in two kidney and one clip (2K1C) rats. Diabetology \& metabolic syndrome, 7(1), 107.

Alam, M. A., Sagor, A. T., Tabassum, N., Ulla, A., Shill, M. C., Rahman, G. M. S., ... Reza, H. M. (2018). Caffeic acid rich Citrus macroptera peel powder supplementation prevented oxidative stress, fibrosis and hepatic damage in $\mathrm{CCl} 4$ treated rats. Clinical Phytoscience, $4(1), 14$

Alam, P., Raka, M. A., Khan, S., Sarker, J., Ahmed, N., Nath, P. D., ... Taher Sagor, M. A. (2018). A clinical review of the effectiveness of tomato (Solanum lycopersicum) against cardiovascular dysfunction and related metabolic syndrome. Journal of Herbal Medicine. doi: https://doi.org/10.1016/j.hermed.2018.09.006

Alderton, W. K., Cooper, C. E., \& Knowles, R. G. (2001). Nitric oxide synthases: structure, function and inhibition. Biochemical Journal, 357(3), 593-615.

Ali, A., Kaur, G., Hamid, H., Abdullah, T., Ali, M., Niwa, M., \& Alam, M. (2003). Terminoside A, a new triterpene glycoside from the bark of Terminalia arjuna inhibits nitric oxide production in murine macrophages. Journal of Asian natural products research, 5(2), 137-142.

Anavi, S., Eisenberg-Bord, M., Hahn-Obercyger, M., Genin, O., Pines, M., \& Tirosh, O. (2015). The role of iNOS in cholesterol-induced liver fibrosis. Laboratory investigation, 95(8), 914.

Asano, K., Chee, C., Gaston, B., Lilly, C. M., Gerard, C., Drazen, J. M., \& Stamler, J. S. (1994). Constitutive and inducible nitric oxide synthase gene expression, regulation, and activity in human lung epithelial cells. Proceedings of the National Academy of Sciences, 91(21), 10089-10093.

AT Sagor, M., M Mohib, M., S Azam, M., Rahman, A., T Tanmoy, F., K Chowdhury, W., ... A Alam, M. (2016). Angiotensin-II, a Potent Peptide, Participates in the Development of Hepatic Dysfunctions. Immunology, Endocrine \& Metabolic
Agents in Medicinal Chemistry (Formerly Current Medicinal Chemistry-Immunology, Endocrine and Metabolic Agents), 16(3), 161-177.

Bae, U.-J., Song, M.-Y., Jang, H.-Y., Lim, J. M., Lee, S. Y., Ryu, J.-H., \& Park, B.-H. (2015). Emodin isolated from Rheum palmatum prevents cytokine-induced $\beta$-cell damage and the development of type 1 diabetes. Journal of Functional Foods, 16, 9-19.

Ballantyne, C. M., \& Nambi, V. (2005). Markers of inflammation and their clinical significance. Atherosclerosis Supplements, 6(2), 21-29.

Baynosa, R. C., Naig, A. L., Murphy, P. S., Fang, X. H., Stephenson, L. L., Khiabani, K. T., Zamboni, W. A. (2013). The effect of hyperbaric oxygen on nitric oxide synthase activity and expression in ischemia-reperfusion injury. journal of surgical research, 183(1), 355-361.

Cabrera-Fuentes, H. A., Ruiz-Meana, M., Simsekyilmaz, S., Kostin, S., Inserte, J., Saffarzadeh, M., ... Barreto, G. (2014). RNase1 prevents the damaging interplay between extracellular RNA and tumour necrosis factor- $\alpha$ in cardiac ischaemia/reperfusion injury. Thrombosis \& Haemostasis, 112(6), 1110-1119.

Chan, E. D., Chan, J., \& Schluger, N. W. (2001). What is the role of nitric oxide in murine and human host defense against tuberculosis? Current knowledge. American journal of respiratory cell and molecular biology, 25(5), 606-612.

Charles, I. G., Palmer, R., Hickery, M. S., Bayliss, M. T., Chubb, A. P., Hall, V. S Moncada, S. (1993). Cloning, characterization, and expression of a cDNA encoding an inducible nitric oxide synthase from the human chondrocyte. Proceedings of the National Academy of Sciences, 90(23), 11419-11423.

Chen, B.-Y., Lin, D. P.-C., Wu, C.-Y., Teng, M.-C., Sun, C.-Y., Tsai, Y.-T., . . Chang, H.-H (2011). Dietary zerumbone prevents mouse cornea from UVB-induced photokeratitis through inhibition of NF-kB, iNOS, and TNF- $\alpha$ expression and reduction of MDA accumulation.

Cho, H. J., Xie, Q., Calaycay, J., Mumford, R. A., Swiderek, K. M., Lee, T. D., \& Nathan, C. (1992). Calmodulin is a subunit of nitric oxide synthase from macrophages. Journal of experimental medicine, 176(2), 599-604.

Chow, B. S. M., Chew, E. G. Y., Zhao, C., Bathgate, R. A., Hewitson, T. D., \& Samuel, C. S (2012). Relaxin signals through a RXFP1-pERK-nNOS-NO-cGMP-dependent pathway to up-regulate matrix metalloproteinases: the additional involvement of iNOS. PloS one, 7(8), e42714.

Chowdhury, M. R. H., Sagor, M. A. T., Tabassum, N., Potol, M. A., Hossain, H., \& Alam, M. A (2015). Supplementation of Citrus maxima peel powder prevented oxidative stress, fibrosis, and hepatic damage in carbon tetrachloride (CCI4) treated rats. Evidence-Based Complementary and Alternative Medicine, 2015.

Chowdhury, N. U., Farooq, T., Abdullah, S., Mahadi, A. S., Hasan, M. M., Paran, T. Z., Alam, M. A. (2016). Matrix Metalloproteinases (MMP), a Major Responsible Downstream Signaling Molecule for Cellular Damage-A Review. Molecular Enzymology and Drug Targets.

Costa, M. A., Elesgaray, R., Caniffi, C., Fellet, A., Mac Laughlin, M., \& Arranz, C. (2010). Role of nitric oxide as a key mediator on cardiovascular actions of atrial natriuretic peptide in spontaneously hypertensive rats. American Journal of Physiology-Heart and Circulatory Physiology, 298(3), H778-H786.

Crump, C., Sundquist, J., Winkleby, M. A., \& Sundquist, K. (2017). Interactive effects of obesity and physical fitness on risk of ischemic heart disease. International journal of obesity (2005), 41(2), 255

Csiszar, A., Labinskyy, N., Jimenez, R., Pinto, J. T., Ballabh, P., Losonczy, G., ... Ungvari, Z (2009). Anti-oxidative and anti-inflammatory vasoprotective effects of caloric restriction in aging: role of circulating factors and SIRT1. Mechanisms of ageing and development, 130(8), 518-527.

Csont, T., Viappiani, S., Sawicka, J., Slee, S., Altarejos, J. Y., Batinić-Haberle, I., \& Schulz, R. (2005). The involvement of superoxide and iNOS-derived NO in cardiac dysfunction induced by pro-inflammatory cytokines. Journal of molecular and cellular cardiology, 39(5), 833-840.

Daff, S., Sagami, I., \& Shimizu, T. (1999). The 42-amino acid insert in the FMN domain of neuronal nitric-oxide synthase exerts control over $\mathrm{Ca} 2+/$ calmodulin-dependent electron transfer. Journal of Biological Chemistry, 274(43), 30589-30595.

Das, A., Xi, L., \& Kukreja, R. C. (2005). Phosphodiesterase-5 inhibitor sildenafil preconditions adult cardiac myocytes against necrosis and apoptosis Essential role of nitric oxide signaling. Journal of Biological Chemistry, 280(13), 12944-12955.

Das, S., Alagappan, V. K., Bagchi, D., Sharma, H. S., Maulik, N., \& Das, D. K. (2005). Coordinated induction of iNOS-VEGF-KDR-eNOS after resveratrol consumption: A potential mechanism for resveratrol preconditioning of the heart. Vascular pharmacology, 42(5), 281-289.

Depre, C., Havaux, X., Renkin, J., Vanoverschelde, J. L. J., \& Wijns, W. (1999). Expression of inducible nitric oxide synthase in human coronary atherosclerotic plaque. Cardiovascular research, 41(2), 465-472.

Depré, C., Wijns, W., Robert, A. M., Renkin, J. P., \& Havaux, X. (1997). Pathology of unstable plaque: correlation with the clinical severity of acute coronary syndromes. Journal of the American College of Cardiology, 30(3), 694-702.

Dhillon, S. S., Mastropaolo, L. A., Murchie, R., Griffiths, C., Thöni, C., Elkadri, A., ... Guo, C. (2014). Higher activity of the inducible nitric oxide synthase contributes to very early onset inflammatory bowel disease. Clinical and translational gastroenterology, 5(1), e46.

Dwivedi, S. (2007). Terminalia arjuna Wight \& Arn.-a useful drug for cardiovascular disorders. Journal of Ethnopharmacology, 114(2), 114-129.

Eckel, R. H. (1997). Obesity and heart disease. Circulation, 96(9), 3248-3250.

Eggers, K. M., Oldgren, J., Nordenskjöld, A., \& Lindahl, B. (2004). Diagnostic value of serial measurement of cardiac markers in patients with chest pain: limited value of adding myoglobin to troponin I for exclusion of myocardial infarction. American heart journal, 148(4), 574-581.

Escames, G., Khaldy, H., León, J., González, L., \& Acuña-Castroviejo, D. (2004). Changes in iNOS activity, oxidative stress and melatonin levels in hypertensive patients treated with lacidipine. Journal of hypertension, 22(3), 629-635.

Fathy, M., Khalifa, E. M., \& Fawzy, M. A. (2018). Modulation of inducible nitric oxide synthase pathway by eugenol and telmisartan in carbon tetrachloride-induced liver injury in rats. Life sciences.

Ferrari, P. F., Palmieri, D., Casazza, A. A., Aliakbarian, B., Perego, P., \& Palombo, D. (2015). TNF $\alpha$-induced endothelial activation is counteracted by polyphenol extract from UV-stressed cyanobacterium Arthrospira platensis. Medicinal Chemistry 
Research, 24(1), 275-282

Ferreiro, C. R., Chagas, A. C. P., Carvalho, M. H. C., Dantas, A. P., Jatene, M. B., de Souza, L. C. B., \& da Luz, P. L. (2001). Influence of hypoxia on nitric oxide synthase activity and gene expression in children with congenital heart disease: a novel pathophysiological adaptive mechanism. Circulation, 103(18), 2272-2276.

Fukumura, D., Gohongi, T., Kadambi, A., Izumi, Y., Ang, J., Yun, C.-O., .. J Jain, R. K. (2001). Predominant role of endothelial nitric oxide synthase in vascular endothelial growth factor-induced angiogenesis and vascular permeability. Proceedings of the National Academy of Sciences, 98(5), 2604-2609.

Funakoshi, H., Kubota, T., Kawamura, N., Machida, Y., Feldman, A. M., Tsutsui, H., .. Takeshita, A. (2002). Disruption of inducible nitric oxide synthase improves $\beta$-adrenergic inotropic responsiveness but not the survival of mice with cytokine-induced cardiomyopathy. Circulation research, 90(9), 959-965.

Funakoshi, H., Kubota, T., Machida, Y., Kawamura, N., Feldman, A. M., Tsutsui, H., Takeshita, A. (2002). Involvement of inducible nitric oxide synthase in cardiac dysfunction with tumor necrosis factor- $\alpha$. American Journal of Physiology-Heart and Circulatory Physiology, 282(6), H2159-H2166.

Gupta, A., Rhodes, G. J., Berg, D. T., Gerlitz, B., Molitoris, B. A., \& Grinnell, B. W. (2007) Activated protein $\mathrm{C}$ ameliorates LPS-induced acute kidney injury and downregulates renal INOS and angiotensin 2. American Journal of Physiology-Renal Physiology, 293(1), F245-F254.

Ham, Y.-M., Ko, Y.-J., Song, S.-M., Kim, J., Kim, K.-N., Yun, J.-H., . . Yoon, W.-J. (2015) Anti-inflammatory effect of litsenolide B2 isolated from Litsea japonica fruit via suppressing NF-kB and MAPK pathways in LPS-induced RAW264. 7 cells. Journal of functional foods, $13,80-88$.

Haywood, G. A. Tsao, P. S., Heiko, E., Mann, M. J., Keeling P. J., Trindade, P. T., ... Bishopric, N. H. (1996). Expression of inducible nitric oxide synthase in human heart failure. Circulation, 93(6), 1087-1094.

Heger, J., Gödecke, A., Flögel, U., Merx, M. W., Molojavyi, A., Kühn-Velten, W. N., \& Schrader, J. (2002). Cardiac-specific overexpression of inducible nitric oxide synthase does not result in severe cardiac dysfunction. Circulation research, 90(1), 93-99

Heron, M., \& Anderson, R. N. (2016). Changes in the leading cause of death: recent patterns in heart disease and cancer mortality. Cancer, 400(500,000), 600,000 .

Heymes, C., Bendall, J. K., Ratajczak, P., Cave, A. C., Samuel, J.-L., Hasenfuss, G., \& Shah, A. M. (2003). Increased myocardial NADPH oxidase activity in human heart failure. Journal of the American College of Cardiology, 41(12), 2164-2171.

Ishibashi, M., Hiasa, K.-i., Zhao, Q., Inoue, S., Ohtani, K., Kitamoto, S., ... Kura, S. (2004). Critical role of monocyte chemoattractant protein-1 receptor CCR2 on monocytes in hypertension-induced vascular inflammation and remodeling. Circulation research, 94(9), 1203-1210.

Islam, M. N., Choi, R. J., Jin, S. E., Kim, Y. S., Ahn, B. R., Zhao, D., ... Choi, J. S. (2012). Mechanism of anti-inflammatory activity of umbelliferone 6 -carboxylic acid isolated from Angelica decursiva. Journal of ethnopharmacology, 144(1), 175-181.

Islam, M. N., Ishita, I. J., Jin, S. E., Choi, R. J., Lee, C. M., Kim, Y. S., ... Choi, J. S. (2013) Anti-inflammatory activity of edible brown alga Saccharina japonica and its constituents pheophorbide $a$ and pheophytin a in LPS-stimulated RAW 264.7 macrophage cells. Food and Chemical Toxicology, 55, 541-548.

Janakiram, N. B., \& Rao, C. V. (2012). iNOS-selective inhibitors for cancer prevention: promise and progress. Future medicinal chemistry, 4(17), 2193-2204.

Janssen-Heininger, Y. M., Macara, I., \& Mossman, B. T. (1999). Cooperativity between Oxidants and Tumor Necrosis Factor in the Activation of Nuclear Factor (NF)-к B: Requirement of Ras/Mitogen-Activated Protein Kinases in the Activation of NF-k B by Oxidants. American journal of respiratory cell and molecular biology, 20(5), 942-952.

Jiang, Q., Elson-Schwab, I., Courtemanche, C., \& Ames, B. N. (2000). $p$-Tocopherol and its major metabolite, in contrast to $\alpha$-tocopherol, inhibit cyclooxygenase activity in macrophages and epithelial cells. Proceedings of the National Academy of Sciences, 97(21), 11494-11499.

Jin, M., Suh, S.-J., Yang, J. H., Lu, Y., Kim, S. J., Kwon, S., . . Ahn, G. W. (2010). Anti-inflammatory activity of bark of Dioscorea batatas DECNE through the inhibition of iNOS and COX-2 expressions in RAW264. 7 cells via NF-KB and ERK1/2 inactivation. Food and chemical toxicology, 48(11), 3073-3079.

Jung, H. A., Jin, S. E., Ahn, B. R., Lee, C. M., \& Choi, J. S. (2013). Anti-inflammatory activity of edible brown alga Eisenia bicyclis and its constituents fucosterol and phlorotannins in LPS-stimulated RAW264. 7 macrophages. Food and Chemical Toxicology, 59, 199-206.

Kapoor, D., Vijayvergiya, R., \& Dhawan, V. (2014). Terminalia arjuna in coronary artery disease: ethnopharmacology, pre-clinical, clinical \& safety evaluation. Journal of ethnopharmacology, 155(2), 1029-1045

Kapur, S., Marcotte, B., \& Marette, A. (1999). Mechanism of adipose tissue iNOS induction in endotoxemia. American Journal of Physiology-Endocrinology and Metabolism, 276(4), E635-E641.

Kengatharan, K. M., De Kimpe, S., Robson, C., Foster, S. J., \& Thiemermann, C. (1998). Mechanism of gram-positive shock: identification of peptidoglycan and lipoteichoic acid moieties essential in the induction of nitric oxide synthase, shock, and multiple organ failure. Journal of Experimental Medicine, 188(2), 305-315.

Keyes, K. T., Ye, Y., Lin, Y., Zhang, C., Perez-Polo, J. R., Gjorstrup, P., \& Birnbaum, Y. (2010). Resolvin E1 protects the rat heart against reperfusion injury. American Journal of Physiology-Heart and Circulatory Physiology, 299(1), $\mathrm{H} 153-\mathrm{H} 164$

Khan, M. I., Ostadhadi, S., Mumtaz, F., Momeny, M., Moghaddaskho, F., Hassanipour, M. . . Dehpour, A. R. (2017). Thalidomide attenuates the development and expression of antinociceptive tolerance to $\mu$-opioid agonist morphine through I-arginine-iNOS and nitric oxide pathway. Biomedicine \& Pharmacotherapy, $85,493-502$

Khan, S., \& Jena, G. (2014). Sodium butyrate, a HDAC inhibitor ameliorates eNOS, iNOS and TGF-B1-induced fibrogenesis, apoptosis and DNA damage in the kidney of juvenile diabetic rats. Food and chemical toxicology, 73, 127-139.
Khanduja, K. L., Sohi, K. K., Pathak, C. M., \& Kaushik, G. (2006). Nimesulide inhibits lipopolysaccharide-induced production of superoxide anions and nitric oxide and iNOS expression in alveolar macrophages. Life sciences, 78(15), 1662-1669.

Kibbe, M. R., Li, J., Nie, S., Watkins, S. C., Lizonova, A., Kovesdi, I., ... Tzeng, E. (2000). Inducible nitric oxide synthase (iNOS) expression upregulates p21 and inhibits vascular smooth muscle cell proliferation through p42/44 mitogen-activated protein kinase activation and independent of p53 and cyclic guanosine monophosphate. Journal of vascular surgery, 31(6), 1214-1228.

Korkmaz, B., Buharalioglu, K., Sahan-Firat, S., Cuez, T., Demiryurek, A. T., \& Tunctan, B. (2011). Activation of MEK1/ERK1/2/iNOS/sGC/PKG pathway associated with peroxynitrite formation contributes to hypotension and vascular hyporeactivity in endotoxemic rats. Nitric Oxide, 24(3), 160-172.

Lechner, M., Lirk, P., \& Rieder, J. (2005). Inducible nitric oxide synthase (iNOS) in tumor biology: the two sides of the same coin. Paper presented at the Seminars in cancer biology.

Lee, D.-H., Cho, H. J., Kim, J.-T., Choi, J. S., \& Joo, C.-K (2001). Expression of vascular endothelial growth factor and inducible nitric oxide synthase in pterygia. Cornea, 20(7), 738-742

Lee, H.-H., Paudel, K. R., \& Kim, D.-W. (2015). Terminalia chebula fructus inhibits migration and proliferation of vascular smooth muscle cells and production of inflammatory mediators in RAW 264.7. Evidence-Based Complementary and Alternative Medicine, 2015

Lee, J. K., Sayers, B. C., Chun, K.-S., Lao, H.-C., Shipley-Phillips, J. K., Bonner, J. C., \& Langenbach, R. (2012). Multi-walled carbon nanotubes induce COX-2 and iNOS expression via MAP kinase-dependent and-independent mechanisms in mouse RAW264. 7 macrophages. Particle and fibre toxicology, 9(1), 14

Li, X., Ye, X., Li, X., Sun, X., Liang, Q., Tao, L., . . Chen, J. (2011). Salidroside protects against MPP+-induced apoptosis in PC12 cells by inhibiting the NO pathway. Brain research, 1382, 9-18.

Li, Y., Shen, L., \& Luo, H. (2016). Luteolin ameliorates dextran sulfate sodium-induced colitis in mice possibly through activation of the Nrf2 signaling pathway. Int Immunopharmacol, 40, 24-31.

Lim, H.-W., Kumar, H., Kim, B.-W., More, S. V., Kim, I.-W., Park, J.-I., . . Choi, D.-K. b-Asarone (cis-2, 4, 5-trimethoxy-1-allyl phenyl), attenuates pro-inflammatory mediators by inhibiting NF-jB signaling and the JNK pathway in LPS activated BV-2 microglia cells.

Liu, F.-q., Zhang, X.-I., Gong, L., Wang, X.-p., Wang, J., Hou, X.-g., . . Zhang, Y. (2011). Glucagon-like peptide 1 protects microvascular endothelial cells by inactivating the PARP-1/iNOS/NO pathway. Molecular and cellular endocrinology, 339(1-2), 25-33.

Liu, X.-m., Peyton, K. J., Wang, X., \& Durante, W. (2012). Sildenafil stimulates the expression of gaseous monoxide-generating enzymes in vascular smooth muscle cells via distinct signaling pathways. Biochemical pharmacology, 84(8), 1045-1054

Loh, S. Y., Giribabu, N., \& Salleh, N. (2017). Changes in plasma aldosterone and electrolytes levels, kidney epithelial sodium channel (ENaC) and blood pressure in normotensive WKY and hypertensive SHR rats following gonadectomy and chronic testosterone treatment. Steroids.

Lowenstein, C. J., \& Padalko, E. (2004). iNOS (NOS2) at a glance. Journal of cell science, $117(14), 2865-2867$

Luoma, J. S., Strålin, P., Marklund, S. L., Hiltunen, T. P., Särkioja, T., \& Ylä-Herttuala, S. (1998). Expression of extracellular SOD and iNOS in macrophages and smooth muscle cells in human and rabbit atherosclerotic lesions: colocalization with epitopes characteristic of oxidized LDL and peroxynitrite-modified proteins. Arteriosclerosis, thrombosis, and vascular biology, 18(2), 157-167.

MacMicking, J., Xie, Q.-W., \& Nathan, C. (1997). Nitric oxide and macrophage function. Annual review of immunology, 15(1), 323-350.

MacMicking, J. D., North, R. J., LaCourse, R., Mudgett, J. S., Shah, S. K., \& Nathan, C. F. (1997). Identification of nitric oxide synthase as a protective locus against tuberculosis. Proceedings of the National Academy of Sciences, 94(10), 5243-5248

Marumo, T., Nakaki, T., Hishikawa, K., Hirahashi, J., Suzuki, H., Kato, R., \& Saruta, T. (1995). Natriuretic peptide-augmented induction of nitric oxide synthase through cyclic guanosine 3', 5'-monophosphate elevation in vascular smooth muscle cells. Endocrinology, 136(5), 2135-2142.

Mayer, B., \& Hemmens, B. (1997). Biosynthesis and action of nitric oxide in mammalian cells. Trends in biochemical sciences, 22(12), 477-481

Metwaly, H., Ebrahem, M. A.-M., \& Saku, T. (2014). Vascular endothelial growth factor (VEGF) and inducible nitric oxide synthase (iNOS) in oral lichen planus: An immunohistochemical study for the correlation between vascular and inflammatory reactions. Journal of Oral and Maxillofacial Surgery, Medicine, and Pathology, 26(3), 390-396.

Mogensen, J., Murphy, R. T., Shaw, T., Bahl, A., Redwood, C., Watkins, H., ... McKenna, W. J. (2004). Severe disease expression of cardiac troponin $C$ and T mutations in patients with idiopathic dilated cardiomyopathy. Journal of the American College of Cardiology, 44(10), 2033-2040.

Mohib, M. M., Afnan, K., Paran, T. Z., Khan, S., Sarker, J., Hasan, N., ... Sagor, M. A. T. (2017). Beneficial Role of Citrus Fruit Polyphenols Against Hepatic Dysfunctions: A Review. Journal of dietary supplements, 1-29.

Mohib, M. M., Hasan, I., Chowdhury, W. K., Chowdhury, N. U., Mohiuddin, S., Sagor, M. A. T., ... Alam, M. A. (2016). Role of angiotensin ii in hepatic inflammation through MAPK pathway: A review. Hepatitis.

Mohib, M. M., Rabby, S. F., Paran, T. Z., Hasan, M. M., Ahmed, I., Hasan, N., ... Mohiuddin, S. (2016). Protective role of green tea on diabetic nephropathy-A review. Cogent Biology, 2(1), 1248166

Mohib, M. M., Rabby, S. M. F., Paran, T. Z., Hasan, M. M., Ahmed, I., Hasan, N., ... Hsu, T.-C. (2016). Protective role of green tea on diabetic nephropathy -A review. Cogent Biology, 1248166. doi: 10.1080/23312025.2016.1248166

Müller-Werdan, U., Schumann, H., Fuchs, R., Reithmann, C., Loppnow, H., Koch, S., Jungblut, P. (1997). Tumor Necrosis Factora (TNF $\alpha$ ) is Cardiodepressant in Pathophysiologically Relevant Concentrations Without Inducing Inducible Nitric Oxide-(NO)-Synthase (iNOS) or Triggering Serious Cytotoxicity. Journa of molecular and cellular cardiology, 29(11), 2915-2923. 
Mungrue, I. N., Gros, R., You, X., Pirani, A., Azad, A., Csont, T., .. Husain, M. (2002a) Cardiomyocyte overexpression of iNOS in mice results in peroxynitrite generation, heart block, and sudden death. The Journal of clinical investigation, 109(6), 735-743

Mungrue, I. N., Gros, R., You, X., Pirani, A., Azad, A., Csont, T., ... Husain, M. (2002b). Cardiomyocyte overexpression of iNOS in mice results in peroxynitrite generation, heart block, and sudden death. The Journal of clinical investigation, 109(6), 735

Nathan, C. (1992). Nitric oxide as a secretory product of mammalian cells. The FASEB journal, 6(12), 3051-3064

Pădureanu, V., Enescu, A. Ş., Siloşi, I., Forțofoiu, M., Enescu, A., Bogdan, M., ... Mita, A. (2017). The association between chronic pancreatitis and the iNOS-2087A> G polymorphism. Romanian Journal of Internal Medicine, 55(2), 89-95.

Palmer, J., Guillard, F., Laurijssens, B., Wentz, A., Dixon, R \& Williams, P. (2009). A randomised, single-blind, placebo-controlled, adaptive clinical trial of GW274150, a selective iNOS inhibitor, in the treatment of acute migraine. Cephalalgia, 29(1), 124

Papapetropoulos, A., García-Cardeña, G., Madri, J. A., \& Sessa, W. C. (1997). Nitric oxide production contributes to the angiogenic properties of vascular endothelial growth factor in human endothelial cells. The Journal of clinical investigation, 100(12), 3131-3139.

Piplani, H., Vaish, V., \& Sanyal, S. N. (2012). Dolastatin 15, a mollusk linear peptide, and Celecoxib, a selective cyclooxygenase-2 inhibitor, prevent preneoplastic colonic lesions and induce apoptosis through inhibition of the regulatory transcription factor NF-kB and an inflammatory protein, iNOS. European Journal of Cancer Prevention, 21(6), 511-522.

Ramlagan, P., Rondeau, P., Planesse, C., Neergheen-Bhujun, V. S., Fawdar, S., Bourdon, E., \& Bahorun, T. (2017). Punica granatum L. mesocarp suppresses advanced glycation end products (AGEs)-and $\mathrm{H} 2 \mathrm{O} 2$-induced oxidative stress and pro-inflammatory biomarkers. Journal of Functional Foods, 29, 115-126.

Rasoanaivo, P., Wright, C. W., Willcox, M. L., \& Gilbert, B. (2011). Whole plant extracts versus single compounds for the treatment of malaria: synergy and positive interactions. Malaria Journal, 10(1), S4.

Reza, H. M., Sagor, M. A. T., \& Alam, M. A. (2015). Iron deposition causes oxidative stress, inflammation and fibrosis in carbon tetrachloride-induced liver dysfunction in rats. Bangladesh Journal of Pharmacology, 10(1), 152-159.

Reza, H. M., Tabassum, N., Sagor, M. A. T., Chowdhury, M. R. H., Rahman, M., Jain, P., \& Alam, M. A. (2016). Angiotensin-converting enzyme inhibitor prevents oxidative stress, inflammation, and fibrosis in carbon tetrachloride-treated rat liver. Toxicology mechanisms and methods, 26(1), 46-53.

Rodrigues, J. P. F., Caldas, I. S., Gonçalves, R. V., Almeida, L. A., Souza, R. L. M., \& Novaes, R. D. (2017). S. mansoni-T. cruzi co-infection modulates arginase-1/iNOS expression, liver and heart disease in mice. Nitric Oxide, 66, 43-52.

Romano, B., Pagano, E., Orlando, P., Capasso, R., Cascio, M. G., Pertwee, R., ... Borrelli, F. (2016). Pure $\Delta$ 9-tetrahydrocannabivarin and a Cannabis sativa extract with high content in $\Delta$ 9-tetrahydrocannabivarin inhibit nitrite production in murine peritoneal macrophages. Pharmacological Research, 113, 199-208.

Ryu, S., Shin, J.-S., Cho, Y.-W., Kim, H. K., Paik, S. H., Lee, J. H., . . Lee, K.-T. (2013). Fimasartan, anti-hypertension drug, suppressed inducible nitric oxide synthase expressions via nuclear factor-kappa B and activator protein-1 inactivation. Biological and Pharmaceutical Bulletin, 36(3), 467-474.

Sagor, A. T., Chowdhury, M. R. H., Tabassum, N., Hossain, H., Rahman, M. M., \& Alam, M. A. (2015). Supplementation of fresh ucche (Momordica charantia L. var. muricata Willd) prevented oxidative stress, fibrosis and hepatic damage in $\mathrm{CCl} 4$ treated rats. BMC complementary and alternative medicine, 15(1), 115.

Sagor, M. A. T., Mohib, M., Tabassum, N., Ahmed, I., \& Reza, H. (2016). Fresh seed supplementation of Syzygium cumini attenuated oxidative stress, inflammation, fibrosis, iron overload, hepatic dysfunction and renal injury in acetaminophen induced rats. Journal of Drug Metabolism \& Toxicology, $7(2)$.

Sagor, M. A. T., Reza, H. M., Tabassum, N., Rahman, M. M., \& Alam, M. A. (2018). Fresh Bitter Melon Fruit (Momordica charantia) Attenuated Oxidative Stress, Fibrosis and Renal Injury in Carbon Tetrachloride Treated Rats. Dhaka University Journal of Pharmaceutical Sciences, 16(2), 205-214.

Sagor, M. A. T., Tabassum, N., Potol, M. A., \& Alam, M. A. (2015). Xanthine oxidase inhibitor, allopurinol, prevented oxidative stress, fibrosis, and myocardial damage in isoproterenol induced aged rats. Oxidative medicine and cellular longevity, 2015.

Sagor, M. A. T., Tabassum, N., Potol, M. A., \& Alam, M. A. (2015). Xanthine Oxidase Inhibitor, Allopurinol, Prevented Oxidative Stress, Fibrosis, and Myocardial Damage in Isoproterenol Induced Aged Rats. Oxidative Medicine and Cellula Longevity, 2015, 9. doi: 10.1155/2015/478039

Salerno, J. C., Harris, D. E., Irizarry, K., Patel, B., Morales, A. J., Smith, S. M., ... Jones, C. L. (1997). An autoinhibitory control element defines calcium-regulated isoforms of nitric oxide synthase. Journal of Biological Chemistry, 272(47) 29769-29777.

Salvemini, D., Nucci, G., Sneddon, J. M., \& Vane, J. R. (1989). Superoxide anions enhance platelet adhesion and aggregation. British journal of pharmacology, 97(4), $1145-1150$.

Sangartit, W., Pakdeechote, P., Kukongviriyapan, V., Donpunha, W., Shibahara, S., \& Kukongviriyapan, U. (2016). Tetrahydrocurcumin in combination with deferiprone attenuates hypertension, vascular dysfunction, baroreflex dysfunction, and oxidative stress in iron-overloaded mice. Vascular Pharmacology, 87, 199-208.

Sarady, J. K., Zuckerbraun, B. S., Bilban, M., Wagner, O., Usheva, A., Liu, F., ... Otterbein, L. E. (2004). Carbon monoxide protection against endotoxic shock involves reciprocal effects on iNOS in the lung and liver. The FASEB journal, 18(7), 854-856.

Satoh, M., Nakamura, M., Tamura, G., Makita, S., Segawa, I., Tashiro, A., ... Hiramori, K. (1997). Inducible nitric oxide synthase and tumor necrosis factor-alpha in myocardium in human dilated cardiomyopathy. Journal of the American College of Cardiology, 29(4), 716-724

Seccombe, J. F., Pearson, P. J., \& Schaff, H. V. (1994). Oxygen radical—mediated vascular injury selectively inhibits receptor-dependent release of nitric oxide from canine coronary arteries. The Journal of thoracic and cardiovascular surgery, 107(2), 505-509.

Seo, S., Shin, J-S. Lee, W.-S., Rhee, Y. K., Cho, C.-W.,Hong H.-D. \& Lee, K.-T. (2017). Anti-colitis effect of Lactobacillus sakei K040706 via suppression of inflammatory responses in the dextran sulfate sodium-induced colitis mice model. Journal of Functional Foods, 29, 256-268.

Shabeeh, H., Khan, S., Jiang, B., Brett, S., Melikian, N., Casadei, B., ... Shah, A. M. (2017). Blood Pressure in Healthy Humans Is Regulated by Neuronal NO SynthaseNovelty and Significance. Hypertension, 69(5), 970-976.

Shimabukuro, M., Ohneda, M., Lee, Y., \& Unger, R. H. (1997). Role of nitric oxide in obesity-induced beta cell disease. Journal of Clinical Investigation, 100(2), 290.

Simsekyilmaz, S., Cabrera-Fuentes, H. A., Meiler, S., Kostin, S., Baumer, Y., Liehn, E. A., ... Zernecke, A. (2013). The role of extracellular RNA in atherosclerotic plaque formation in mice. Circulation, CIRCULATIONAHA. 113.002562

Sun, Y., Carretero, O. A., Xu, J., Rhaleb, N.-E., Wang, F., Lin, C., . . Yang, X.-P. (2005). Lack of inducible NO synthase reduces oxidative stress and enhances cardiac response to isoproterenol in mice with deoxycorticosterone acetate-salt hypertension. Hypertension, 46(6), 1355-1361.

Taylor, B. S., \& Geller, D. A. (2000). Molecular regulation of the human inducible nitric oxide synthase (iNOS) gene. Shock (Augusta, Ga.), 13(6), 413-424

Tikellis, C., Thomas, M. C., Harcourt, B. E., Coughlan, M. T., Pete, J., Bialkowski, K., Forbes, J. M. (2008). Cardiac inflammation associated with a Western diet is mediated via activation of RAGE by AGEs. American Journal of Physiology-Endocrinology and Metabolism, 295(2), E323-E330.

Vannini, F., Kashfi, K., \& Nath, N. (2015). The dual role of iNOS in cancer. Redox biology, 6, 334-343.

Vejlstrup, N. G., Bouloumie, A., Boesgaard, S., Andersen, C. B., Nielsen-Kudsk, J. E., Mortensen, S. A., ... Aldershvile, J. (1998). Inducible nitric oxide synthase (iNOS) in the human heart: expression and localization in congestive heart failure. Journal of molecular and cellular cardiology, 30(6), 1215-1223.

Wang, W. Z., Fang, X. H., Stepheson, L. L., Khiabani, K. T., \& Zamboni, W. A. (2004). NOS upregulation attenuates vascular endothelial dysfunction in the late phase of ischemic preconditioning in skeletal muscle. Journal of orthopaedic research 22(3), 578-585.

Westermann, D., Lindner, D., Kasner, M., Zietsch, C., Savvatis, K., Escher, F. ... Riad, A. (2010). Cardiac inflammation contributes to changes in the extracellular matrix in patients with heart failure and normal ejection fraction. Circulation: Heart Failure, CIRCHEARTFAILURE. 109.931451

Wever, R. M., Lüscher, T. F., Cosentino, F., \& Rabelink, T. J. (1998). Atherosclerosis and the two faces of endothelial nitric oxide synthase. Circulation, 97(1), 108-112.

Wong, M.-L., Rettori, V., Amer, A.-S., Bongiorno, P. B., Canteros, G., McCann, S. M., Licinio, J. (1996). Inducible nitric oxide synthase gene expression in the brain during systemic inflammation. Nature medicine, 2(5), 581-584

Xia, M., Ling, W. H., Ma, J., Kitts, D. D., \& Zawistowski, J. (2003). Supplementation of diets with the black rice pigment fraction attenuates atherosclerotic plaque formation in apolipoprotein e deficient mice. The Journal of nutrition, 133(3), 744-751.

Xia, X., Ling, W., Ma, J., Xia, M., Hou, M., Wang, Q., ... Tang, Z. (2006). An anthocyanin-rich extract from black rice enhances atherosclerotic plaque stabilization in apolipoprotein E-deficient mice. The Journal of nutrition, 136(8), 2220-2225.

Xu, W., Charles, I. G., Moncada, S., Gorman, P., Sheer, D., Liu, L., \& Emson, P. (1994). Mapping of the genes encoding human inducible and endothelial nitric oxide synthase (NOS2 and NOS3) to the pericentric region of chromosome 17 and to chromosome 7, respectively. Genomics, 21(2), 419-422.

Xuan, Y.-T., Guo, Y., Han, H., Zhu, Y., \& Bolli, R. (2001). An essential role of the JAK-STAT pathway in ischemic preconditioning. Proceedings of the National Academy of Sciences, 98(16), 9050-9055.

Yang, B., Larson, D. F., \& Watson, R. R. (2004). Modulation of iNOS activity in age-related cardiac dysfunction. Life sciences, 75(6), 655-667

Ying, L., \& Hofseth, L. J. (2007). An emerging role for endothelial nitric oxide synthase in chronic inflammation and cancer. Cancer Research, 67(4), 1407-1410.

Yoda, Y., Amagase, K. Kato, S., Tokioka, S., Murano, M., Kakimoto, K.,... Higuchi, K. (2010). Prevention by lansoprazole, a proton pump inhibitor, of indomethacin-induced small intestinal ulceration in rats through induction of heme oxygenase-1. Journal of Physiology and Pharmacology, 61(3), 287.

Yu, G., Cheng, M., Wang, W., Zhao, R., \& Liu, Z. (2017). Involvement of WNK1-mediated potassium channels in the sexual dimorphism of blood pressure. Biochemical and Biophysical Research Communications, 485(2), 255-260.

Yu, X. W., Chen, Q., Kennedy, R. H., \& Liu, S. J. (2005). Inhibition of sarcoplasmic reticular function by chronic interleukin-6 exposure via iNOS in adult ventricular myocytes. The Journal of physiology, 566(2), 327-340.

Zhang, J., Peng B. \& Chen, X. (2005). Expressions of nuclear factor $\mathrm{kB}$, inducible nitric oxide synthase, and vascular endothelial growth factor in adenoid cystic carcinoma of salivary glands: correlations with the angiogenesis and clinical outcome. Clinical Cancer Research, 11(20), 7334-7343.

Submit your next manuscript to Journal of Angiotherapy published by EMAN Research

- Convenient online submission
- Thorough peer review
- No space constraints or color figure charges
- Immediate publication on acceptance
- Inclusion in Australian National Libraray and Google Scholar
- Both Open (80-100\% subsidized APC by ER) \& non-open access option
Submit your manuscript at
https://angiotherapy.emanresearch.org

